\begin{tabular}{l} 
PIBEHЬ ЖИТTЯ \\
STANDARD OF LIVING \\
\hline
\end{tabular}

Cite: Ngwakwe, C. C. (2020). Gender equality and extreme poverty alleviation in sub-Saharan Africa. Demography and Social Economy, 4 (42), 56-70. doi: https://doi.org/10.15407/dse2020.04.056

https://doi.org/10.15407/dse2020.04.056

УДК $364.22,364.29$

JEL CLASSIFICATION: I3

COLLINS C NGWAKWE, PhD (Professor of Accounting)

Turfloop Graduate School of Leadership, Faculty of Management and Law

University of Limpopo, Republic of South Africa

Address: Webster Street, Polokwane, Republic of South Africa

Email: collins.ngwakwe@ul.ac.za

ORCID: 0000-0002-6954-8897

Scopus ID: 36698325300

\title{
GENDER EQUALITY AND EXTREME POVERTY ALLEVIATION IN SUB-SAHARAN AFRICA
}

This article assesses the link between the four pillars of gender equality and extreme poverty in sub-Saharan Africa. Accordingly, the objective of the paper is to empirically examine whether the four pillars of gender equality, namely women's health, women education, political participation of women and economic participation facilitate extreme poverty alleviation in sub-Saharan Africa. Data were collected from the World Bank development indicators and World Economic Forum Global Gender Gap Index for 25 sub-Saharan African countries whose data appear on both indexes for three years into the SDGs era. The paper applied a quantitative approach with secondary data on poverty gap index drawn from the World Economic Forum Poverty Gap Index for sub-Saharan Africa. Data for twenty-five sub-Saharan African countries were analysed using the fixed-effect panel data regression approach using the Hauseman model selection test. Findings from the analysis indicate that, ceteris paribus, an increase in the threegender equity variables namely economic participation of women, education of women and political participation and leadership of women in sub-Saharan Africa has a significant potential to reduce extreme poverty in sub-Saharan Africa within the sample of study. Since the findings of this study have shown that extreme poverty can be reduced through increased women participation in economic activity, education and leadership, the SDG of poverty alleviation can be improved in sub-Saharan Africa through better government provision of economic, educational and leadership opportunities for women such as providing women with free-interest small business start-up funds, free education for women and supporting women to ascend and survive in political and leadership positions in sub-Saharan Africa through a balanced quota for female leadership positions. Given that the women's health variable did not prove to be significant on extreme poverty, further research is recommended to separate the health variable into rural health and urban health variables in order to examine the possibility that either of the health clusters might contribute significantly to reducing extreme poverty. This paper contributes to 
Gender equality and extreme poverty alleviation in sub-Saharan Africa

existing literature by providing an empirical evidence to show that gender equality in sub-Saharan Africa is a viable policy strategy for achieving the SDGs 2030 Agenda of extreme poverty eradication in sub-Saharan Africa; the paper also provides empirical model for future study.

Keywords: gender equality, women empowerment, equity, extreme poverty alleviation, subSaharan Africa.

Formulation of the problem. Projection indicates that by 2030 sub-Saharan Africa will only manage to reduce its extreme poverty from the current $33.5 \%$ to $24 \%$ (Brookings Institution, 2019). With this seemingly sluggish trend, Africa might not meet the SDG 1 (eradicating extreme poverty by 2030 (Downtoearth, 2018)). This implies that approximately 377 million Africans will still be living on less than $\$ 1.90$ a day (Brookings Institution, 2019). The worrying implication thus is that by year 2030, $86 \%$ to $90 \%$ of world's extreme poor will live in sub-Saharan Africa if the current trajectory of poverty in sub-Saharan Africa continues (Downtoearth, 2018; McKay \& Steinhauser, 2018). The utmost concern is that the women of sub-Saharan Africa seem to be more affected than their male counterparts chiefly because of a growing rate of sub-Saharan African women who are single parents, which exacerbates the spate of poverty (Hamplová \& Hamplová, 2011). This results in almost half of the children of sub-Saharan Africa living in extreme poverty (World Bank, 2018). Reversing this trend is urgently needed, but this requires the need for improved female gender equality through various aspects of women empowerment such as education empowerment, economic empowerment and giving the women access to effective reproductive health care (McKay \& Steinhauser, 2018; Hodal, 2018). The core problem of this paper is that prior research on gender equality in subSaharan Africa has not been classified according to the four streams of the World Economic Forum(WEF) dimensions of gender equality, which are economic participation, education empowerment, political empowerment, health (WEF, 2019). Accordingly, this paper contributes a novelty by applying the WEF classification of gender equality and uses it to analyse the possibility of extreme poverty reduction in sub-Saharan Africa. Hence, the first attempt in sub-Saharan African article to link SDG goal 1 and SDG goal 5 (applying the WEF) classification (so far rarely covered in the literature).

Relevance of research. The paper's significance is that it suggests alternative approach to speed up extreme poverty alleviation, which is urgently needed in sub-Saharan Africa. This is necessary because Africa's patriarchy-dominated society has continued to obstruct reasonable progression of women's role in economic activities; hence policy makers remain obscured to the valuable impact of women to poverty reduction in sub-Saharan Africa. This paper is therefore relevant for policymakers in sub-Saharan Africa as it provides empirical evidence based in sub-Saharan African countries that equitable participation and empowerment of women in education, health, economic activities and political 
roles is a veritable alternative to assisting in alleviating extreme poverty in subSaharan Africa by 2030.

The purpose of the article. The purpose of this article is to analyse the relationship between the WEF four pillars of gender equality and extreme poverty eradication in sub-Saharan Africa.

The scientific novelty of the article. This is the first empirical paper from sub-Saharan Africa, which is operationalized and modelled on the WEF's four pillars of gender equality, namely economic participation, education, health and political empowerment by relating these variables empirically with extreme poverty reduction (SDG goal 1) in sub-Saharan Africa. Additionally, the paper provides a novel model for further research on gender and poverty reduction in sub-Saharan Africa and provides empirical proof of the need to apply many years of observation for future research and women and poverty reduction in order to produce a reasonable result.

Analysis of recent studies and publications. Some African and international studies highlight gender issues that are related to poverty (Mantsurov \& Khrapunova, 2019; Macleod, 1999 Asongu \& Odhiambo, 2020). Gender inequality exacerbates poverty in Africa, therefore poverty reduction programmes must integrate gender equality policies (Vyas-Doorgapersad, 2014; Awumbila, 2006). An earlier researcher concluded that the starting point for extreme poverty eradication is gender equality (Sachs, 2005). This is important for sub-Saharan Africa because women in sub-Saharan Africa are more vulnerable to extreme poverty (Nwosu \& Ndinda, 2018). In another related research, Kes and Swaminathan (2006) provides and empirical proof to show that time usage can be linked with gender and poverty in sub-Saharan Africa. Asongu and Odhiambo (2019) finds empirical evidence to show that economic participation of women reduces inequality in sub-Saharan Africa. In a recent study by Asongu and Odhiambo (2020), they applied the generalised method of moment (GMM) to provide an empirical proof that a certain level of gender inequality threshold becomes inimical to women's economic contribution to society. Korosteleva and Stępień-Baig (2020) provide an empirical analysis to show that empowering women into entrepreneurial roles contributes significantly to poverty alleviation in transition economies. In their research on labour market transition in Ukraine, researchers found gender inequity wherein most young women are employed in unpaid family labour (Libanova, Cymbal, Lisogor, Marchenko, \& Iarosh, 2014). In their study in Ukraine, Aksyonova and Kurylo, (2018) find an inclination amongst young women to postpone fertility to later age whilst empowering themselves educationally and economically; this is contrary to the case in sub-Saharan Africa where young women indulge in early procreation, which exacerbates the level of poverty and obviates the chances of young women to achieve educational and economic empowerment (Macleod, 1999). Furthermore, a recent study in Ukraine has found empirical proof to show that some single women in Ukraine experien- 
ce poverty arising from inability to work while taking care of children as a lone parent (Mantsurov \& Khrapunova, 2019). Applying a systematic approach to rural gender inequality, a recent research found that household gender inequality is rife in rural areas more than in urban areas and that such inequality exacerbates extreme poverty (Steffens, Knerr \& García, 2020). In their analysis of obscured issues that catalyse poverty, Odera and Mulusa (2020) found that existing inequality such as unpaid or underpaid women labour, child labour, denial of women education and violence against women contribute to the upsurge of poverty. A closely related research has found that up to $41 \%$ of the population in sub-Saharan Africa live in extreme poverty, of which women are the dominant demographic group, and concludes that empowering rural women is essential in reducing extreme poverty in sub-Saharan Africa (Shaver, 2020). None of the foregoing extant literature has empirically examined the linkage between the WEF's four pillars of gender equality (SDG goal 5) and extreme poverty reduction (SDG goal 1) in sub-Saharan Africa.

Research method. The fixed effect (FE) panel data regression analysis was used. This is a preferred approach because FE models helps in controlling for omitted variable bias owing to unobserved heterogeneity if this heterogeneity is constant over time; accordingly, previous authors recommend the fixed effect panel analysis given this ability to enhance control of omitted variable (Jansen \& Cope, 2012). Since extreme poverty eradication was not achieved for subSaharan Africa during the Millennium Development Goals era, which ended in 2015, the paper included data for three years within the Millennium Development Goals era (2013-2015) and three years within the SDG era (2016-2018), which was used to form a panel for twenty five (25) select sub-Saharan African countries. The selection was based on those who have complete data for the six years period. Since there are 46 sub-Saharan African countries, the sample of 25 countries represented $54 \%$ of sub-Saharan African countries. The sample of 25 countries was based on data availability. Future researchers are encouraged to repeat this research when more data would have been available for more countries. Data were collected from the World Bank development indicators and World Economic Forum' Global Gender Gap Index for 25 sub-Saharan African countries whose data appear on both indexes for three years into the SDGs era (2016 to 2018), which is three years into the sustainable development era; not all the sub-Saharan African countries have had their full data coverage available, hence the 25 countries' data were used in the analysis. Therefore, using the WEF's four pillars of gender equality, the following analysis model of four independent variables and one dependent variable (which is extreme poverty) was used:

$$
\begin{aligned}
& \text { Extreme Poverty Eradication }[\mathrm{Y}]=\beta_{0}+\beta_{1} \mathrm{X}_{1}+\beta_{2} \mathrm{X}_{2}+ \\
& +\beta_{3} \mathrm{X}_{3}+\beta_{4} \mathrm{X}_{4}+\beta_{5} \mathrm{X}_{5}+\varepsilon
\end{aligned}
$$


Where: $\mathrm{Y}=$ Extreme Poverty Eradication; $\beta_{0}=$ model intercept; $\mathrm{X}_{1}=$ economic participation of women; $\mathrm{X}_{2}=$ education of women; $\mathrm{X}_{3}+=$ women's health care; $\mathrm{X}_{4}=$ political participation of women, and $\beta_{5} \mathrm{X}_{5}=$ income per capita for the lowest ten percentile (according to World Bank). $\beta_{1}-\beta_{5}=$ model coefficients; $\varepsilon=$ error (accounting for other independent variables not accounted for).

The World Economic Forum (2020) provides annual Global Gender Gap Report (GGGR), which is an index on the extent to which regions have narrowed their existing gender gap with women. The rating is thus provided by the World Economic Forum, which is available in the web archives of the World Economic Forum's GGGR. The organisation has rated regional and country performance on gender gap closure on a scale of $0-1$ (or $0 \%-100 \%$ ), a higher rating indicates higher achievement of gender gap closure in a region or country. Accordingly, the World Economic Forum (2020) GGGR provides their rating on the following four pillars of gender equality (Table 1).

Main Findings. Model Summary (Holding other factors constant): drawing from the results, the following model summary presented as a representation of gender equality implication on extreme poverty alleviation in sub-Saharan Africa. Table 2 presents the research findings of this article, which indicate that, ceteris paribus, an increase in three gender equality variables, namely economic participation of women, education of women and political participation of women in sub-Saharan Africa has the potential to reduce extreme poverty in subSaharan Africa.

This significance of the obtained results is indicated by the low p-values in these three variables, which are less than the probability of 0.05 and the negative signs in the regression coefficients of the three variables, which are economic participation of women ( $p$-value $=0.00837$ with a coefficient of: -0.10002 ), education of women ( $\mathrm{p}$-value $=0.01220$, with a coefficient of -0.24400$)$ and political participation of women ( $\mathrm{p}$-value $=0.00244$, with a coefficient of -0.02233 ). However, the health variable did not prove to be significantly related to extreme poverty alleviation in sub-Saharan Africa with a high p-value of 0.21133 , which is greater than 0.05 (5\%) significant level. Also the lowest ten percentile per capita income (according to World Bank 2020) was added to the independent

Table 1. World Economic Forum Four Pillars of Gender Gap Rating

\begin{tabular}{|l|c|c|}
\hline \multicolumn{1}{|c|}{ WEF's Four Pillars of Gender Equality } & \multicolumn{2}{c|}{ WEF Rating Scale } \\
\hline 1. Economic participation and opportunity for women & $0-1$ & Or 0 \%-100\% \\
2. Educational attainment of women & $0-1$ & Or 0 \%-100\% \\
3. Health and survival of women & $0-1$ & Or 0\%-100\% \\
4. Political empowerment of women & $0-1$ & Or 0\%-100\% \\
\hline
\end{tabular}

Source: Table complied by author with data from the World Economic Forum (2020). 
variables; the income variable is significant at a p-value of 0.0012 . In addition to the above mentioned performance of main independent variables, time dummies were used to take care of time effects on variables; however, the time dummies are not significant. Further test of autocorrelation was conducted in Table 3 below; according to Field (2009), a Durbin Watson p-value of 1.5 and 2.5 is indicative of no autocorrelation. Therefore, the Durbin Watson test with a p-value of 2.100 for this article shows there is no autocorrelation (see Table 3 below). Accordingly, the results show that the WEF's four pillars of gender equity variables (except health) show significant negative relationship with extreme

Table 2. Fixed-effects Results

(Gender Equality and Extreme Poverty Reduction)

\begin{tabular}{|l|c|c|c|}
\hline & Coefficient & Std. Error & p-value \\
\hline const & -0.20011 & 0.125500 & 0.00022 \\
EcoPart & -0.10002 & 0.014402 & 0.00837 \\
Edu & -0.24400 & 0.011240 & 0.01220 \\
Health & -1.01122 & 0.123881 & 0.21133 \\
PolEmp & -0.02233 & 0.016120 & 0.00244 \\
Income & -0.12240 & 0.03441 & 0.00125 \\
dt_2 & 0.072940 & 0.01806 & 0.13891 \\
dt_3 & 0.063931 & 0.07729 & 0.23100 \\
dt_4 & 0.022310 & 0.01105 & 0.18729 \\
dt_5 & 0.013711 & 0.03719 & 0.22201 \\
dt_6 & 0.092210 & 0.02806 & 0.08842 \\
\hline
\end{tabular}

Source: Author's results.

Table 3. Model Selection and Estimation

\begin{tabular}{|c|c|}
\hline Hausman Test: P-value & 0.0001 (therefore, random effect not appropriate) \\
\hline F-test & $\begin{array}{l}\mathrm{F}(29,120)=8.69 ; \mathrm{P} \text {-value }(\mathrm{F})=0.0001 \text { (therefore, random } \\
\text { effect not appropriate) }\end{array}$ \\
\hline R-squared & 0.87060 \\
\hline Adjusted R-squared & 0.78255 \\
\hline Autocorrelation & $\begin{array}{l}\text { Durbin-Watson at a value }=2.100 \text { shows absence of } \\
\text { autocorrelation }\end{array}$ \\
\hline Normality of residual & $\begin{array}{l}\text { Test indicates the errors are normally distributed } \\
\text { with a p-value }=0.4010\end{array}$ \\
\hline Heteroskedasticity & $\begin{array}{l}\text { White's test for heteroskedasticity indicate absence } \\
\text { of heteroskedasticity at a P-value }=0.2144\end{array}$ \\
\hline
\end{tabular}

Source: Author's results.

ISSN 2072-9480. Демограбія та соціальна економіка. 2020, № 4 (42) 
poverty reduction. This indicates that increase in economic participation of women, education of women and political participation of women in subSaharan Africa contributes to reducing extreme poverty in sub-Saharan Africa, and thus points to the need for governments in sub-Saharan Africa to bolster gender equality policy to enhance continuous improvement in gender equality in this region given its contribution to this important United Nation's SDG goal of extreme poverty reduction. The result of this article confirms (Asongu \& Odhiambo, 2019) assertion that gender equality in sub-Saharan Africa can be linked to SDG 1, which is extreme poverty eradication.

The statistical results were further confirmed with descriptive statistics regarding the behaviour of the variables in Table 4 below. The extent of normal distribution of variables was tested; according to experts, variables that are normally distributed should not exhibit a distribution pattern whose skewness and/ or kurtosis exceeds +1 or fall below -1 (Hair et al., 2017). Accordingly, Table 4 below shows that both the skewness and kurtosis of the research data are normal distributions since none of them are above +1 and none are below -1 . In addition, the coefficient of variable $(\mathrm{CV})$ in Table 4 show that the coefficients are low, which is an indication that the variables have very low variation from the mean.

Table 5 below shows that sub-Saharan African countries have not done much to close the gender gap since the end of five years into the UN Sustainable Development Goals era. Rather, many countries have retrogressed as the difference between 2015 and 2020 are showing negative numbers. This is further confirmed in Table 6, which shows that majority of sub-Saharan African countries have women's representation in parliaments at below $15 \%$, which is a source of concern.

The statistical estimates of the data behaviour are further confirmed by a visual graphical behaviour of the variables, which appear in Figure 1 below showing that the oscillations of data are not spiky. Furthermore, unlike low

Table 4. Descriptive Statistics

\begin{tabular}{|l|c|l|l|l|l|l|}
\hline & Ext.Poverty & Eco.Part & Education & Health & Polit. Emp & Income \\
\hline Mean & 7295045.24 & 0.693180 & 0.859067 & 0.952367 & 0.186200 & 1.70667 \\
Median & 5640980 & 0.697500 & 0.869500 & 0.973000 & 0.172000 & 1.30000 \\
Minimum & 375336 & 0.273000 & 0.572000 & 0.376000 & 0.520000 & 0.70000 \\
Maximum & 21400554 & 0.911000 & 1.00000 & 0.980000 & 0.404000 & 4.10000 \\
Std. Dev. & 2438970 & 0.0933160 & 0.100872 & 0.0949384 & 0.010200 & 0.71331 \\
C.V. & 0.3343 & 0.1346 & 0.117420 & 0.0996869 & 0.052109 & 0.41795 \\
Skewness & 0.946 & 0.4154 & 0.438411 & 0.872991 & 0.535431 & 0.69352 \\
Kurtosis & 0.167 & 0.6583 & 0.460403 & 0.159212 & 0.710479 & 0.04932 \\
\hline
\end{tabular}

Source: Author's results. 
Gender equality and extreme poverty alleviation in sub-Saharan Africa

Table 5. Extent of Gender Gap Closure

in sub-Saharan Africa (SSA) five Years into the SDGs Era

\begin{tabular}{|l|c|c|c||l|c|c|c|}
\hline SSA Country & 2015 & 2020 & Diff & SSA Country & 2015 & 2020 & Diff \\
\hline Benin & 0.625 & 0.658 & 0.033 & Liberia & 0.652 & 0.685 & 0.033 \\
Botswana & 0.71 & 0.709 & -0.001 & Madagascar & 0.698 & 0.719 & 0.021 \\
Burkina Faso & 0.651 & 0.635 & -0.016 & Malawi & 0.701 & 0.664 & -0.037 \\
Burundi & 0.748 & 0.745 & -0.003 & Mali & 0.599 & 0.621 & 0.022 \\
Cameroon & 0.682 & 0.686 & 0.004 & Mauritania & 0.613 & 0.614 & 0.001 \\
Cape Verde & 0.717 & 0.725 & 0.008 & Mauritius & 0.646 & 0.665 & 0.019 \\
Chad & 0.58 & 0.596 & 0.016 & Mozambique & 0.741 & 0.723 & -0.018 \\
Côte d'Ivoire & 0.606 & 0.606 & 0 & Namibia & 0.76 & 0.784 & 0.024 \\
Ethiopia & 0.64 & 0.705 & 0.065 & Nigeria & 0.638 & 0.635 & -0.003 \\
Gambia, The & 0.674 & 0.628 & -0.046 & Rwanda & 0.794 & 0.791 & -0.003 \\
Ghana & 0.704 & 0.673 & -0.031 & Senegal & 0.698 & 0.684 & -0.014 \\
Guinea & 0.618 & 0.642 & 0.024 & South Africa & 0.759 & 0.78 & 0.021 \\
Kenya & 0.719 & 0.671 & -0.048 & Tanzania & 0.718 & 0.713 & -0.005 \\
Lesotho & 0.706 & 0.695 & -0.011 & Zimbabwe & 0.709 & 0.73 & 0.021 \\
\hline
\end{tabular}

Source: Author's Tabulation with Data from WEF (2015 \& 2020).

Table 6. Political Empowerment: sub-Saharan Africa:

Percentage of Women in Parliament

\begin{tabular}{|l|c||l|c|}
\hline \multicolumn{1}{|c|}{ Country } & $\begin{array}{c}\text { Women } \\
\text { in Parliament, } \%\end{array}$ & \multicolumn{1}{c|}{ Country } & $\begin{array}{c}\text { Women in } \\
\text { Parliament, } \%\end{array}$ \\
\hline Botswana & 10.80 & Mali & 27.90 \\
Burkina Faso & 13.40 & Mauritania & 20.30 \\
Burundi & 36.40 & Mauritius & 20.00 \\
Cameroon & 33.90 & Mozambique & 41.20 \\
Congo DR & 12.80 & Namibia & 43.30 \\
Cote d'Ivoire & 11.40 & Niger & 17.00 \\
Djibouti & 26.20 & Nigeria & 3.60 \\
Equatorial Guinea & 21.00 & Republic of Congo & 11.30 \\
Eritrea & 22.00 & Rwanda & 61.30 \\
Eswatini & 9.60 & Sao Tome \& Principe & 14.50 \\
Ethiopia & 38.80 & Senegal & 43.00 \\
Guinea & 16.70 & Sierra Leone & 12.30 \\
Kenya & 21.80 & South Africa & 46.60 \\
Lesotho & 23.30 & Tanzania & 36.90 \\
Liberia & 12.30 & Togo & 18.70 \\
Malawi & 22.90 & Zimbabwe & 31.90 \\
\hline
\end{tabular}

Source: Author's Tabulation with Data from Institute for Democracy \& Electoral Assistance (2020).

ISSN 2072-9480. Демограбія та соціальна економіка. 2020, № 4 (42) 

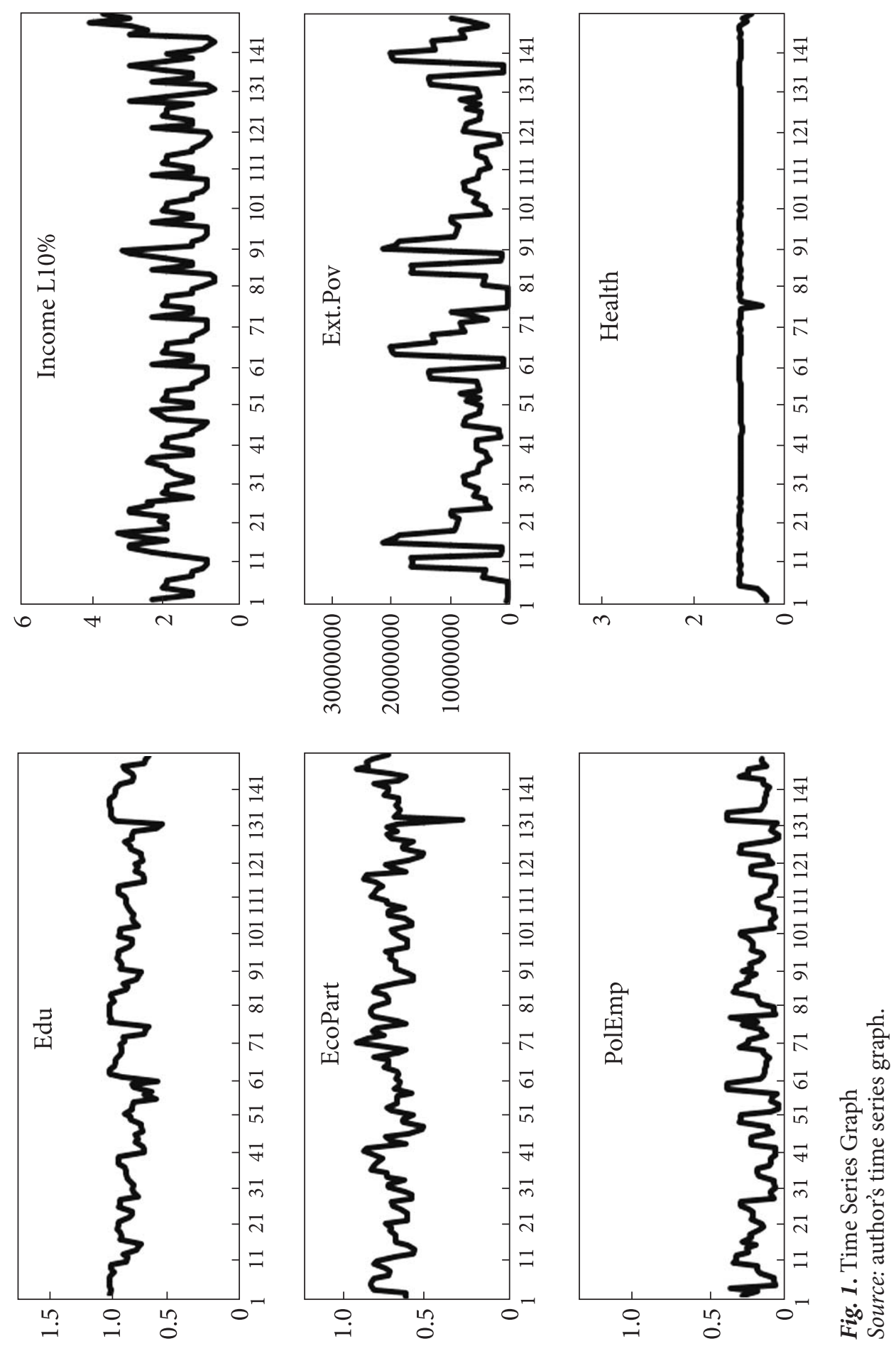


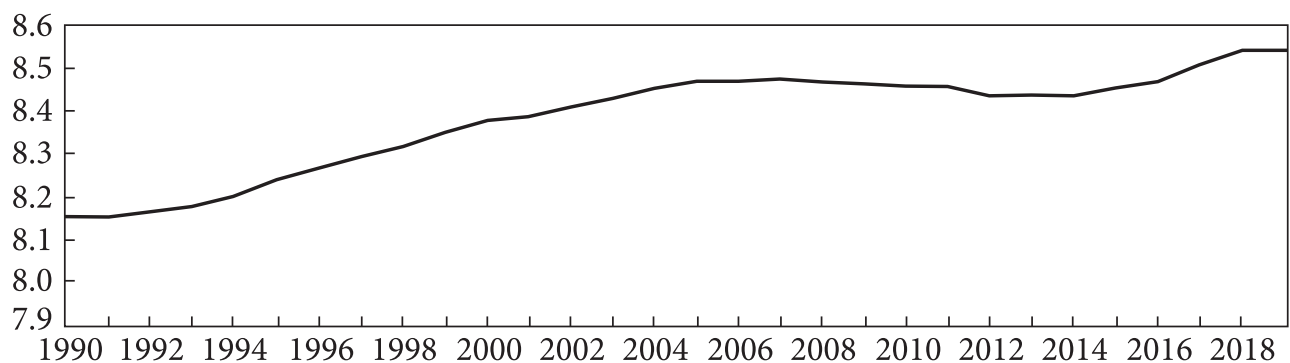

Fig. 2. Economic Participation: Sub-Saharan Africa: \% Female Labour Force Participation Source: Author's graph with Data from the Institute for Democracy \& Electoral Assistance (2020).

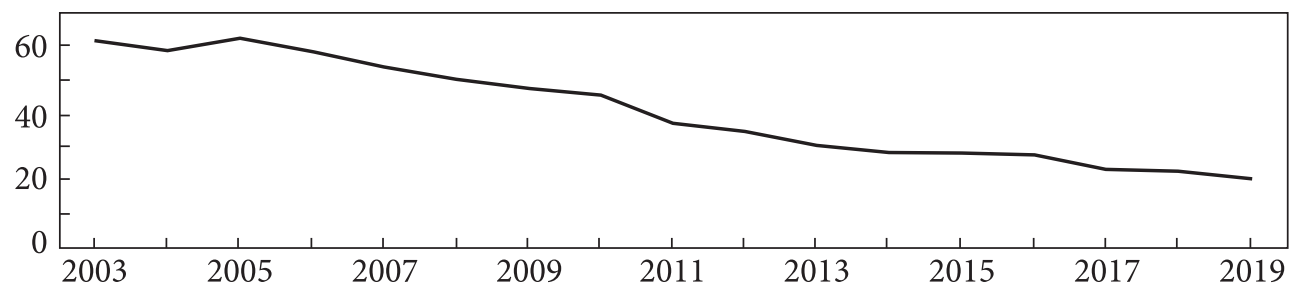

Fig. 3. Economic Participation Time required for Females to Start New Busines in subSaharan Africa

Source: Author's graph with Data from World Bank (2020).

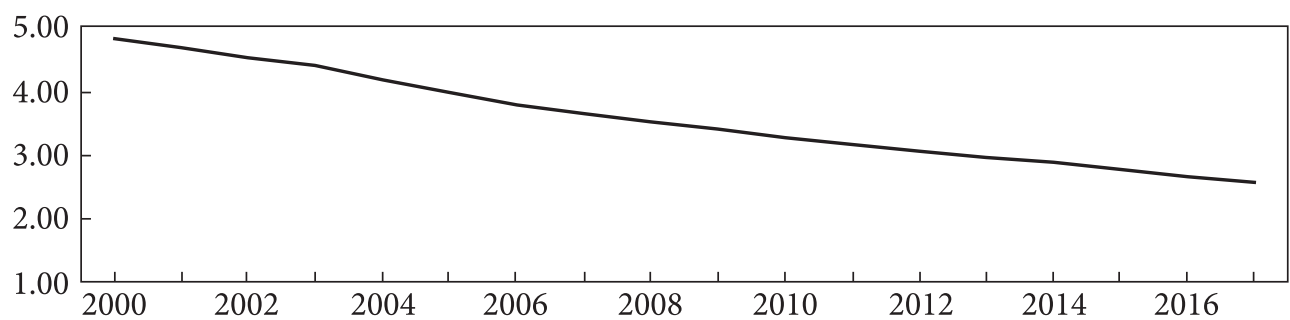

Fig. 4. Health and Survival of women: Sub-Saharan Africa: \% Risk of Maternal death Source: Author's graph with Data from World Bank (2020).

political participation of women in sub-Saharan Africa, Figure 2 below shows that Economic Participation of women in sub-Saharan Africa has fairly increased regarding the percentage of female labour force participation. In addition, improved economic participation of women can also be seen in Figure 3, which shows the reduction in time required for females to start their own new business in sub-Saharan Africa. In terms women's health in sub-Saharan Africa, Figure 4 shows that the risk of maternal death has fallen between the years 2000 and 2017, which is a good development. Regarding education, Figure 5 shows a moderate increase in female progression to secondary education in sub-Saharan Africa, but more is still needed to close the gap that still exists in women's education. Figure 6 demonstrates the very low representation of women in parlia- 


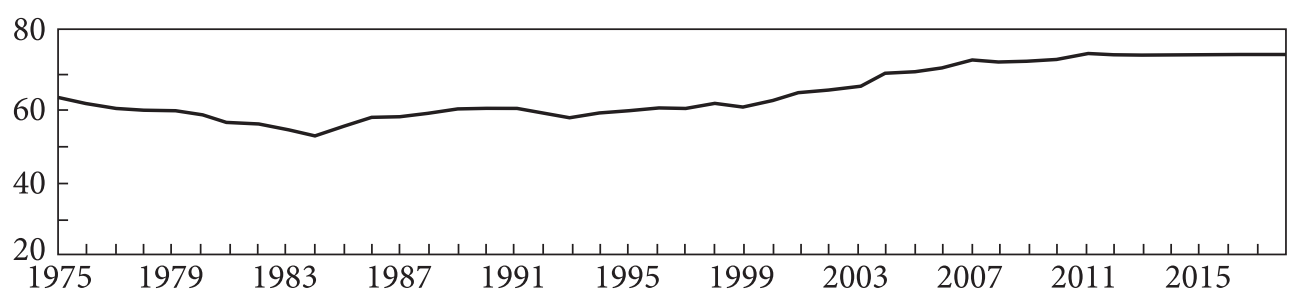

Fig. 5. Education of women: sub-Saharan Africa \% Female Progression to Secondary School Source: Author's graph with Data from World Bank (2020).

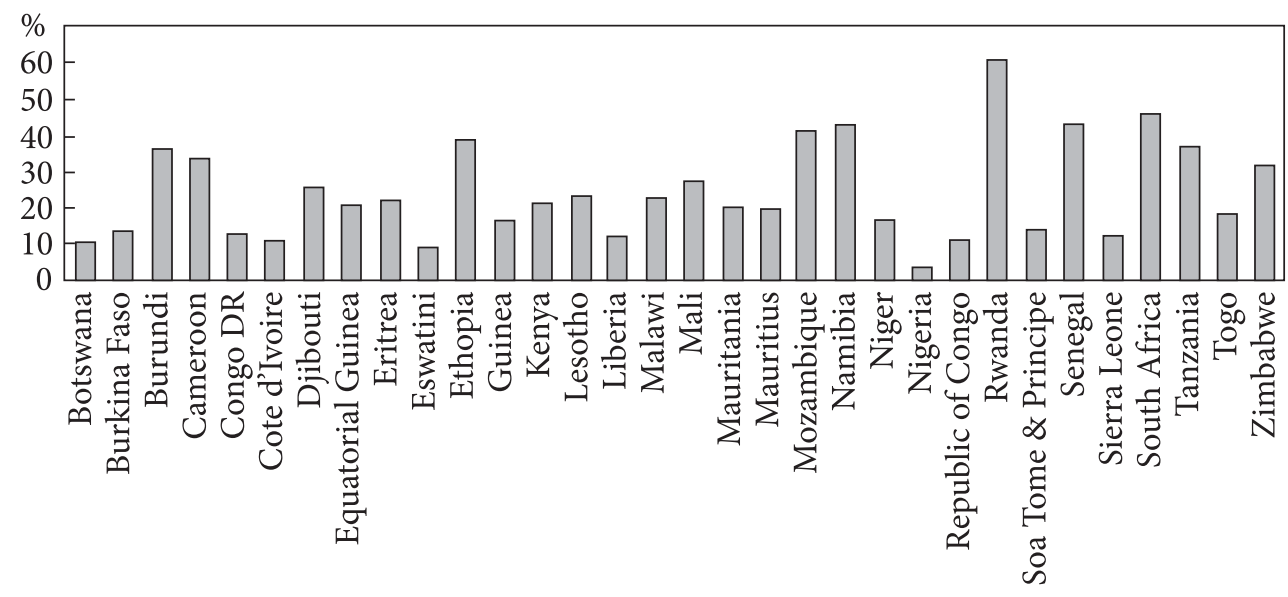

Fig. 6. Political Empowerment: sub-Saharan Africa: Percentage of Women in Parliament Source: Author's graph with Data from the Institute for Democracy \& Electoral Assistance (2020).

ment in sub-Saharan Africa. Only five countries, namely Rwanda, South Africa, Senegal, Namibia and Mozambique, have had a reasonable female gender representation in parliament in sub-Saharan Africa.

Conclusions and prospects of future studies in the field. The article aimed to examine the relationship between gender equality and extreme poverty alleviation in sub-Saharan Africa. This paper is deemed apposite because Africa accounts for up to $70 \%$ of global poverty. Having stepped three years into a new era of global development agenda - SDGs requires an assessment of the four pillars of gender equality to identify the foremost of these factors, which may assist policy makers in driving poverty alleviation goal in sub-Saharan Africa. A panel data from the four pillars of gender equality and extreme poverty data were collected from twenty-five sub-Saharan countries for 6 years. Regression results indicate that, other things being equal, an increase in three pillars of gender equality, namely economic participation of women, education of women and political participation of women in sub-Saharan Africa, can catalyse reduction in extreme poverty in sub-Saharan Africa. 
Gender equality and extreme poverty alleviation in sub-Saharan Africa

Accordingly, based on the paper's findings and on prior literature, the paper makes the following recommendations, which can bolster extreme poverty alleviation in sub-Saharan Africa. Since the findings of this study has shown that extreme poverty can be reduced through increased women participation in economic activity, education and leadership, the SDG regarding poverty alleviation can be improved in sub-Saharan Africa through enhanced government provision of economic, educational and leadership opportunity for women such as providing women with free-interest small business start-up funds to establish small businesses, which can improve women's economic participation. Also the sub-Saharan African government should provide free education for women to accelerate women's educational empowerment in sub-Saharan Africa. The government should also provide enabling support for sub-Saharan African women to ascend and survive in political and leadership positions; this can be done through a balanced quota for female leadership positions.

The article also recommends further research in the following areas. Given that the women's health variable did not prove to be significant on extreme poverty, further research is recommended to separate the health variable into rural health and urban health variables in order to examine the possibility that either of the health clusters might contribute significantly to reducing extreme poverty. In addition, the paper suggested that future research should further explore the influence of effective women's health care on extreme poverty reduction. Perhaps such future research should consider effective health care policy for rural sub-Saharan African women. This is because previous research had identified that there is widespread lack of effective health policy for rural women (Magoma et al., 2010; Mrisho et al. 2009). Given that many sub-Saharan African women dwell in rural areas (Apolotical, 2018), it is imperative to consider effect of health policy for rural women on extreme poverty. The author therefore suggest that future research model should expand the model used in the foregoing results of this paper by including additional variable, namely, effective health policy for rural women in the research model. Hence, whilst this paper has used four independent variables, it is suggested that further research should examine the effect of gender equality on extreme poverty by expanding the model to six independent variables with the addition of effective health policy for rural women.

Thus the suggested expanded model for future research is as follows:

$$
\begin{aligned}
& \text { Extreme Poverty Eradication }[Y]=\beta_{0}+\beta_{1} X_{1}+\beta_{2} X_{2}+\beta_{3} X_{3}+ \\
& +\beta_{4} X_{4}+\beta_{5} X_{5}+\beta_{6} X_{6}+\varepsilon
\end{aligned}
$$

Where: $\mathrm{Y}=$ Extreme Poverty Eradication; $\beta_{0}=$ model intercept; $\mathrm{X}_{1}=$ economic participation of women; $\mathrm{X}_{2}=$ education of women; $\mathrm{X}_{3}+=$ women's health care; $\mathrm{X}_{4}=$ political participation of women; $\beta_{5} \mathrm{X}_{5}=$ health care policy effectiveness; $\beta_{5} X_{5}=$ income per capita; $\beta_{1}-\beta_{5}=$ model coefficients; $\varepsilon=$ error (accounting for other independent variables not accounted for). 
The above suggested future model for researching the effect of gender equality on extreme poverty is important because the literature covered in this article suggests that rural women constitute a quarter of global population and are often ignored by policymakers (Apolitical, 2018). The need is also heightened by the literature assertion, which indicates that three-quarters of world extreme poverty live in rural areas of which $70 \%$ are women (Apolitical, 2018).

\section{REFERENCES}

1. Aksyonova, S. Yu., \& Kurylo, I. (2018). Postponement of Childbirth in UkraineThrough the Prism of Cohort Women. Demography and the Social Economy, 3 (34), 11-25. https:// doi.org/10.15407/dse2018.03.011 [in Ukrainian].

2. Apolitical rural women are a quarter of global population but ignored by policy (2018). apolitical.co Retrieved from https://apolitical.co/solution_article/rural-women-quarterglobal-population-ignored-policy/

3. Asongu, S. A., \& Odhiambo, N. M. (2020). Inequality thresholds, governance and gender economic inclusion in sub-Saharan Africa. International Review of Applied Economics, 34 (1), 94-114.

4. Asongu, S., \& Odhiambo, N. (2019). Inequality and the economic participation of women in Sub-Saharan Africa: An empirical investigation. African Journal of Economic and Management Studies. Retrieved from https://www.emerald.com/insight/content/doi/ 10.1108/AJEMS-01-2019-0016/full/pdf?title=inequality-and-the-economic-participation-of-women-in-sub-saharan-africa-an-empirical-investigation

5. Awumbila, M. (2006). Gender equality and poverty in Ghana: implications for poverty reduction strategies. GeoJournal, 67 (2), 149-161.

6. DowntoEarth (2018). Africa to house 86\% of the world's poorest by 2050. Retrieved from https://www.downtoearth.org.in/news/urbanisation/africa-to-house-86-of-the-world-spoorest-by-2050-61671

7. Field, A. P. (2009). Discovering statistics using SPSS: and sex and drugs and rock ' $n$ ' roll (3rd edition). London: Sage.

8. Hamplová, S. \& Hamplová, D. (2011) Single Motherhood in Sub-Saharan Africa: A Life Course Perspective. Retrieved from https://paa2011.princeton.edu/papers/112136

9. Hair, J. F., Hult, G. T. M., Ringle, C. M., \& Sarstedt, M. (2017). A Primer on Partial Least Squares Structural Equation Modeling (PLS-SEM). 2nd Ed. Thousand Oaks, CA: Sage.

10. Hodal, K. (2018). Global Development: Nearly half all children in sub-Saharan Africa in extreme poverty, report warns The Guardian. Retrieved from https://www.theguardian. com/global-development/2016/oct/05/nearly-half-all-children-sub-saharan-africa-extreme-poverty-unicef-world-bank-report-warns

11. Institute for Democracy \& Electoral Assistance (2020). Percentage of women in Parliament - sub-Saharan Africa. Retrieved from https:/www.idea.int/data-tools/data/ gender-quotas/regions-overview\#Africa

12. Jansen, J. P., \& Cope, S. (2012). Meta-regression models to address heterogeneity and inconsistency in network meta-analysis of survival outcomes. BMC medical research methodology, 12 (1), 152-162.

13. Kes, A., \& Swaminathan, H. (2006). Gender and time poverty in sub-Saharan Africa. Gender, time use, and poverty in sub-Saharan Africa. Retrieved from https://sarpn.org/ documents/d0002049/Gender_Poverty_WorldBank_2006.pdf\#page=27 
Gender equality and extreme poverty alleviation in sub-Saharan Africa

14. Korosteleva, J., \& Stępień-Baig, P. (2020). Climbing the poverty ladder: the role of entrepreneurship and gender in alleviating poverty in transition economies. Entrepreneurship \& Regional Development, 32 (1-2), 197-220. https://doi.org/10.1080/0898562 6.2019.1640482

15. Libanova, E., Cymbal, A., Lisogor, L., Marchenko, I., \& Iarosh, O. (2014). Labour market transitions of young women and men in Ukraine. ILO. Retrieved from http://www.un.org. ua/images/documents/4521/wcms_519747.pdf

16. Macleod, C. (1999). Teenage pregnancy and its 'negative' consequences: Review of South African research - Part 1. South African journal of psychology, 29 (1), 1-7.

17. Magoma, M., Requejo, J., Campbell, O. M., Cousens, S., \& Filippi, V. (2010). High ANC coverage and low skilled attendance in a rural Tanzanian district: a case for implementing a birth plan intervention. BMC pregnancy and childbirth, 10 (1), 13-28.

18. Mantsurov, I. G., \& Khrapunova, Y. V. (2019). Statistical measurement of the inclusive growth characteristics in Ukraine. Demography and Social Economy, 2 (36), 96-108. https://doi.org/10.15407/dse2019.02.096

19. McKay, B. \& Steinhauser, G. (2018). Extreme Poverty Concentrates in Sub-Saharan Africa. The Wall Street Journal. Retrieved from https://www.wsj.com/articles/extreme-poverty-concentrates-in-sub-saharan-africa-1537243201

20. Mrisho, M., Obrist, B., Schellenberg, J. A., Haws, R. A., Mushi, A. K., Mshinda, H., ... \& Schellenberg, D. (2009). The use of antenatal and postnatal care: perspectives and experiences of women and health care providers in rural southern Tanzania. BMC pregnancy and childbirth, 9 (1), 10. Retrieved from https://bmcpregnancychildbirth.biomedcentral. com/articles/10.1186/1471-2393-9-10

21. Nwosu, C. O., \& Ndinda, C. (2018). Gender-based Household Compositional Changes and Implications for Poverty in South Africa. Journal of International Women's Studies, 19 (5), 82-94.

22. Odera, J. A., \& Mulusa, J. (2020). SDGs, Gender Equality and Women's Empowerment: What Prospects for Delivery? In Sustainable Development Goals and Human Rights (pp. 95-118). Springer. Cham.

23. Sachs, J. D. (2005). Can extreme poverty be eliminated? Scientific American, 293 (3), 56-65.

24. Shaver, M. (2020). The Gendered Political Economy of Africa: How the Empowerment of Women in Smallholder Farms Can Spearhead Economic Growth. Retrieved from https:// cedar.wwu.edu/cgi/viewcontent.cgi?article $=1353 \&$ context=wwu_honors

25. Steffens, U., Knerr, B., \& García, J. B. (2020). Intra-Household Gender Equality, Family Organization, and Poverty in Rural Yucatán1. Traditional Smallholder Farmers in a Growing Economy and a Globalized World: Evidence from the State of Yucatan, 10, 163. Kassel University Press, Kassel.

26. Vyas-Doorgapersad, S. (2014). Gender Equality, pro-poor growth and MDG Goal 1 in South African municipal governance: the case of Sedibeng District Municipality. Mediterranean Journal of Social Sciences, 5 (21), 327-337.

27. World Bank (2018). Poverty and inequality. Retrieved from http://povertydata.worldbank. org/poverty/home/

28. World Economic Forum[WEF] (2020) Reports, Retrieved from https://www.weforum. org/reports?year=2019\#filter

Article submitted on 22.07.2020. 


\section{K. К. Нлвакве, $\mathrm{PhD}$ (Бухгалтерський облік)}

Вища школа лідерства Turfloop, факультет управління та права

Університет Лімпопо, Південно-Африканська Республіка

Вебстер-стріт, Полокване, Південно-Африканська Республіка

E-mail: collins.ngwakwe@ul.ac.za

ORCID: 0000-0002-6954-8897

Scopus ID: 36698325300

\section{ГЕНДЕРНА РІВНІСТЬ ТА ПОДОЛАННЯ КРАЙНЬОЇ БІДНОСТІ В КРАЇНАХ АФРИКИ, ЩО РОЗМІЩЕНІ НА ПІВДЕНЬ ВІД САХАРИ}

У изй статті оцінюється зв'язок між чотирма складовими гендерної рівності та крайньою бідністю в країнах Південної Сахари. Відповідно, мета цього документа полягає в емпіричному дослідженні того, чи сприяють зменшенню крайньої бідності в країнах Африки, шо розмімені на південь від Сахари, чотири складові гендерної рівності, а саме - здоров'я жінки, освіта жінок, політична участь жінок та економічна участь. У дослідженні використано дані бази показників розвитку Світового банку та Індексу глобального гендерного розриву Світового економічного форуму для 25 краӥн Абрики, щ, розмімені на південь від Сахари; в часи ЦСР, дані обох індексів доступні упродовж трьох років. У статті застосовувався кількісний підхід із вторинними даними щьодо індексу розриву бідності, узятих із Світового економічного боруму Індексу бідності для країн Африки на південь від Сахари. Дані для двадияти п’яти країн Африки на південь від Сахари були проаналізовані, використовуючи підхід регресії даних на панелі з біксованим ебектом, використовуючи тест вибору моделі Хаусмана. Результати аналізу показують, що збільшення показників, які характеризують три складові, зокрема рівень економічної участі жінок, освіти жінок та політичної участі жінок у Африці на південь від Сахари, може призвести до зменшення крайньої бідності в изх країнах у межах вибірки дослідження. Оскільки результати иьього дослідження показали, що надзвичайну бідність можна зменшити за рахунок посилення участі жінок в економічній діяльності, освіті та лідерстві. ЦСР щодо подолання бідності можуть бути покращені в Африці на південь від Сахари шляхом покращення надання державою жінкам: економічних, освітніх та лідерських можливостей, безкоштовних стартових фондів малого бізнесу, безкоштовної освіти та підтримки щзоо затвердження та виживання на політичних і керівних посадах, через збалансовану квоту на керівні посади жінок. Зважаючи на те, що змінна здоров'я жінок не виявилася значною у надзвичайній бідності, рекомендується подальше дослідження для розділення змінної стану здоров'я на змінні стану здоров'я в містах та селищах, для вивчення можливостей того, щзо будь-який із кластерів охорони здоров'я може істотно сприяти зменшенню екстремальних ситуацій щодо бідності. Ця стаття забезпечує внесок до наявної літератури, надаючи емпіричні докази того, що гендерна рівність у країнах на південь від Сахари є життєздатною стратегічною політикою із досягнення порядку денного ЦСР до 2030 р. щодо викорінення крайньої бідності. Майбутні дослідження мають включати більше африканських країн, оскільки все більше додаткових відповідних даних стають доступними для аналізу.

Ключові слова: гендерна рівність, розширення прав і можливостей жінок, справедливість, подолання крайньої бідності, країни Африки на південь від Сахари. 